\title{
The Migratory Response of Labor to Special Economic Zones in the Philippines, 1995-2005
}

\author{
Scott R. Sanders \\ Brigham Young University - Provo, scott_sanders@byu.edu \\ David L. Brown \\ Cornell University
}

Follow this and additional works at: https://scholarsarchive.byu.edu/facpub

Part of the Migration Studies Commons, Other Sociology Commons, Regional Sociology Commons, and the Rural Sociology Commons

\section{Original Publication Citation}

Sanders, Scott R. and David L. Brown. "The Migratory Response of Labor to Special Economic Zones in the Philippines, 1995-2005." Population Research and Policy Review 31 (2012): 1, 141-164.

\section{BYU ScholarsArchive Citation}

Sanders, Scott R. and Brown, David L., "The Migratory Response of Labor to Special Economic Zones in the Philippines, 1995-2005" (2011). Faculty Publications. 4803.

https://scholarsarchive.byu.edu/facpub/4803

This Peer-Reviewed Article is brought to you for free and open access by BYU ScholarsArchive. It has been accepted for inclusion in Faculty Publications by an authorized administrator of BYU ScholarsArchive. For more information, please contact ellen_amatangelo@byu.edu. 


\title{
The Migratory Response of Labor to Special Economic Zones in the Philippines, 1995-2005
}

\author{
Scott R. Sanders • David L. Brown
}

Received: 13 July 2009/ Accepted: 18 October 2011/Published online: 2 November 2011

(C) Springer Science+Business Media B.V. 2011

\begin{abstract}
In the mid 1990s the Filipino government adopted a new export-led development policy in an attempt to attract new investments and lower the unemployment rates throughout the country. The central idea was to provide foreign investors more access to Filipino markets and labor by giving them investor tax breaks and lowering trade tariffs. In return, the government hoped that investors would bring large amounts of capital into designated areas thereby creating new jobs and stimulating the domestic economy. The Filipino created the Philippine Economic Zone Authority (PEZA) and Base Conversion Development Authority (BCDA) to manage the operation of the Special Economic Zones (SEZ) throughout the country. Between 1995 and 2005 PEZA and BCDA approved over 200 new SEZ that have created over four million jobs throughout the country. However, these jobs are concentrated in a small number of regions. This research uses a modified HarrisTodaro model and GIS techniques to examine the inter-regional migration response to the PEZA and BCDA programs' geographically targeted investments. We show that areas with the highest job growth have high rates of in-migration while regions with low SEZ related investments have become migration-sending areas. In addition, our analysis shows that in-migration to SEZ affected areas has tended to surpass available jobs resulting in high unemployment. We show how the HarrisTodaro model in combination with GIS might be used to identify locations for future PEZA and BCDA investments that are less likely to result in regional population loss or growth in unemployment.
\end{abstract}

\footnotetext{
S. R. Sanders $(\bowtie)$

Department of Development Sociology, Cornell University, 115 Warren Hall, Ithaca,

New York 14853, USA

e-mail: srs73@cornell.edu

D. L. Brown

Department of Development Sociology, Cornell University,

338 Warren Hall, Ithaca, New York 14853, USA
} 
Keywords Philippines - Labor migration - Special economic zones · Rural-urban migration · GIS

\section{Introduction and Background}

In the mid 1990s the Philippines adopted an export-led growth economic development policy. Historically the Philippines engaged in protectionist policies under the Marcos administration. These policies were designed to restrict foreign ownership and control over business in the Philippines. However, with the fall of the Marcos regime and the success of the Asian tigers, the Aquino and Ramos administrations believed that Marcos' longstanding protectionist policies had prevented the Philippines from benefiting from the foreign direct investment led economic boom in South East Asia during the late 1980s and early 1990s. The Philippines inability to attract FDI was largely due to the remnant policy and corruption from the Marcos era (Ringuet and Estrada 2003). As a result, in the mid 1990s the Filipino government adopted a new development policy in an attempt to attract FDI.

The theory driving this new policy approach was centered on trade liberalization and had the backing and encouragement of the World Bank and the United States. These policies would also transform the Philippines economy from the inward oriented policies of the Marcos regime to the outward export production-led model that was succeeding in other South East Asian countries. The central idea was to provide investors more access to Filipino markets and labor by easing restrictions on property ownership, providing investors with tax breaks and lowering trade tariffs (Guillermo 1996). In return, the government hoped that investors would focus their investment of industrial capital in designated areas. These investments would create new jobs that would then stimulate regional economies and eventually expand to economic growth for the Philippines as a whole. In addition, the capital investments needed to create new industrial jobs would provide funding for training, infrastructure upgrades and utility improvements for the Philippines (Tolentino 1994). The allure of potential capital, together with pressure from the international community, prompted the Filipino government to pursue large capital investments and adopt an export-led growth strategy.

To implement this new strategy the Filipino government passed two major pieces of legislation, Republic Act No. 7227, otherwise known as the Bases Conversion and Development Act of 1992 and Republic Act No. 7916 (R.A. No. 7916 or the "Act") otherwise known as the Special Economic Zone Act of 1995. These bills created the Base Conversion and Development Authority (BCDA) and the Philippines Economic Zone Authority (PEZA) to help attract foreign investors, and to target special areas within the Philippines thought to be particularly suitable for special economic zones (SEZ). Foreign investments located within SEZ received tax breaks and other financial incentives from the Filipino government. Today, over 200 SEZ have been created throughout the Philippines. These zones are directly responsible for creating millions of new jobs and billions of dollars in foreign investment (Philippines Congressional Planning and Budget Department 2003). At 
the national level, the Philippines' strategy of export-led growth has succeeded in attracting foreign investment and creating new jobs. However, it is unclear how the influx of foreign capital has affected the regional distribution of the population and migration flows within the Philippines. This paper examines how the establishment of SEZ affected and facilitated the creation of new rural to urban migration flows in the Philippines. These new rural to urban migration flows may have outpaced job creation in regions with high concentrations of SEZ, and even lead to an increase in unemployment. Because reliable migration data are not available at the provincial or regional level for the Philippines, the examination of migration in the Philippines can be difficult. However, this paper is able to map predicted changes in migration flows using a modified Harris-Todaro model. Comparing regional wage discrepancies, the Harris-Todaro model can estimate if there is a high propensity of migration from one area to another. The scores estimated by the model are then mapped to show changes in rural to urban migration flows for three different periods, 1990-1995, 1995-2000, 2000-2005.

\section{Creation of Infrastructure to Stimulate Export-Led Development}

In the mid 1990s, BCDA and PEZA actively pursued foreign investment and created SEZ as locations for new development. In 1992, the BCDA began to convert former United States (US) military bases into economic centers for future SEZ (Bases Conversion Development Authority 2006b). The conversion mainly targeted the former US naval base in Subic Bay, Angeles Airbase northwest of Manila and Fort John Hay in the northern Cordillera Administrative Region (CAR). ${ }^{1}$ The conversion of these military bases into SEZ began in 1992, but the first SEZ were not established until after 1995.

In 1995, PEZA was created to establish and manage all SEZ that were not located on former US military bases. While SEZ are the geographic locations of targeted economic development, they vary from extensive economic districts to concentrated development within a single building. PEZA or BCDA used a variety of fiscal incentives to attract business and investors to SEZ in the Philippines. Once an investment is approved by PEZA or BCDA a company can begin operations within the designated SEZ and immediately receive the financial benefits granted to it by PEZA and BCDA. These incentives are diverse and significant. For example, foreign investors can obtain tax and duty-free importation of capital equipment, raw materials, spare parts and supplies; income tax holidays of 4-6 years; a special tax rate of $5 \%$ of gross income earned in lieu of all national and local taxes; tax credits for import substitution; and discounted prices on "underutilized" land (Bases Conversion Development Authority 2006a; Philippines Economic Zone Authority 2006a).

\footnotetext{
1 Based on the 2000 census, the Philippines is divided up into 14 regions, including the Metro Manila area. These regions are administrative divisions that serve primarily to organize the 81 provinces for administrative and statistical convenience. Although the number of regions has changed over time, this paper holds the 14 regions defined in the 2000 census constant throughout the paper.
} 
The SEZ program was also designed to redistribute investment away from the Metro Manila area by developing "underutilized land" into industrial centers. By introducing SEZ into largely rural regions outside of Metro Manila, the Filipino government planned to transform the nation's economy from one based on agriculture to a much greater dependence on industry. This transformation would occur by creating industrial jobs within the SEZ, and by establishing peripheral industries to support the needs of the SEZ, their businesses and employees. For example, the steel industry generated jobs in the mills as well as in other industries providing essential inputs for the mills as well as in other establishments that produce a variety of manufactured exports using the steel. In addition, the government believed that PEZA would generate a positive multiplier stimulating Filipino employers because the day-to-day needs of factory workers and their families were expected to be supplied by Filipino owned establishments (Guillermo 1996). The Filipino government hoped it could transform agricultural regions with relatively few employers per hectare into industrial centers employing thousands of workers and attracting international trade and business.

SEZ created by both BCDA and PEZA vary in size and type of operation from the East Cyber Gate Building in Metro-Manila that houses software engineering firms to the Bataan Export Processing Zone which is over 1,700 hectares and houses factories that produce a broad array of products ranging from garments to agrochemicals (Philippines Economic Zone Authority 2006b). The main investments in SEZ between 1995 and 2001 included electronic parts and products (64.3\%), electrical machinery (13.8\%), and transport/car parts (7.4\%) (Philippines Economic Zone Authority 2006b).

When PEZA and BCDA were created, they were responsible for the operation of a handful of SEZ, however by 2005 the number had grown to over 200 (Fig. 1). ${ }^{2}$ While SEZ have been established throughout the Philippines, they tend to concentrate in particular parts of the country. As can be seen in Fig. 1, PEZA and BCDA especially targeted Regions 3 and 4 for the development of SEZ. One explanation for this concentration is that two former US military bases, Subic Bay and Angeles Airbase, are located in Region 3. These two former bases fall under the BCDA and account for 17 of 45 SEZ in the Region. Another reason for the concentration of SEZ in Regions 3 and 4 is their well-developed infrastructure. In a 2002 study, Makabenta determined that sound infrastructure was the strongest determining factor for investors and PEZA when selecting SEZ sites. Accordingly, strong infrastructure in Regions 3 and 4 made them attractive locations for foreign investors, for PEZA and for BCDA (Makabenta 2002). In addition, PEZA selected Regions 3 and 4 in a conscious effort to spread economic growth from the Metro

\footnotetext{
2 The map below shows the location of all SEZ in the Philippines and divides the Philippines by region. The remainder of the paper will examine how SEZ have impacted the Philippines on a regional level, and are based on the 14 regions defined in the 2000 census. These regions are strictly for statistical geography and have no political offices associated with them. Senators, governors and other political officials are elected at the provincial level. However, regions are used by the census office and other national government agencies as a useful level for reporting sub-national statistics. As a result, the regional level was selected for analysis because consistent and accurate data are available from the Philippines government, while data at the provincial level are more difficult to obtain and are less reliable.
} 

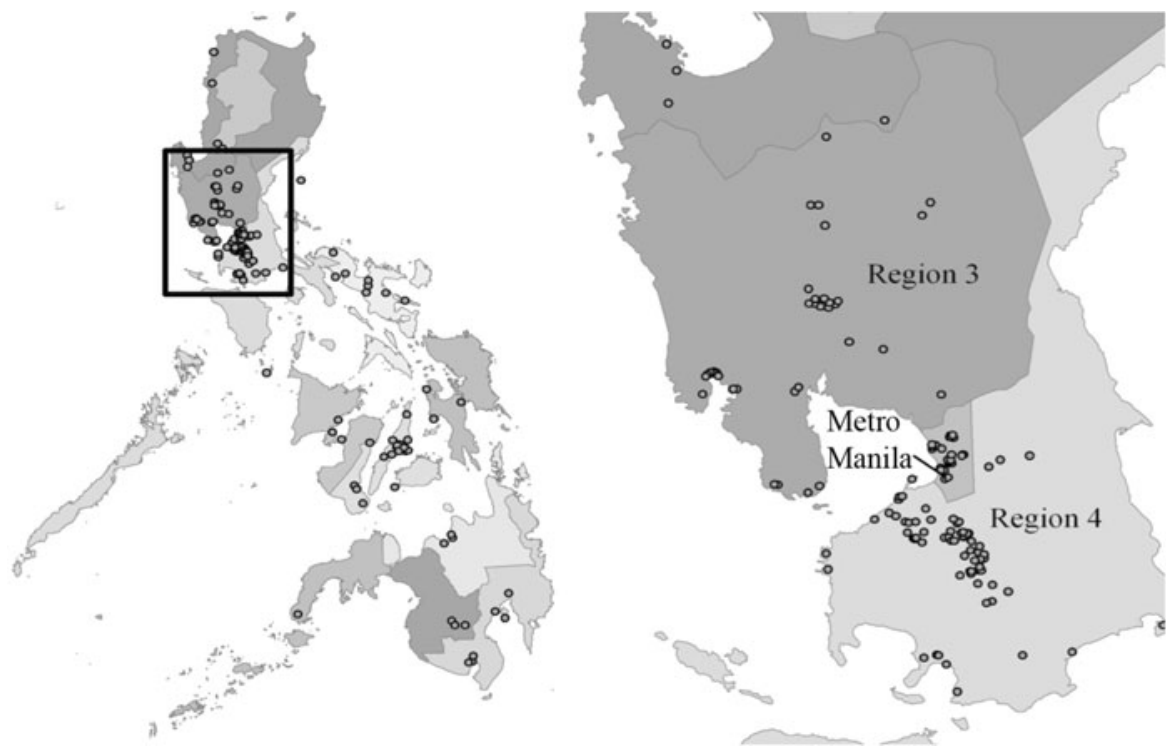

Fig. 1 Location of SEZ, 2005. (Bases Conversion Development Authority 2006a; Philippines Economic Zone Authority 2006a)

Manila area into its surrounding regions. For example, Region 4 was targeted as the location of new manufacturing plants that required large amounts of land because such sites were not available in the Metro Manila area. BCDA and PEZA hoped that this targeted approach for the development of Regions 3 and 4 would increase economic prosperity and lower the region's unemployment rates. The development of these regions would then give investors alternatives to the Metro Manila area (Philippines Economic Zone Authority 2006b).

\section{Have BCDA and PEZA Succeeded in Generating Economic Development?}

Between 1995 and 2005 the BCDA and PEZA reported that over 3.1 million jobs were created within the nation's 200 SEZ (Bases Conversion Development Authority 2001; Bases Conversion Development Authority 2006b; Philippines Economic Zone Authority 2006c). As shown in Table 1, 46.6\% of the new jobs were created in Region 4 and $34.7 \%$ in Region 3. One reason so many more jobs were created there than in any other region, approximately two million between 1995 and 2005, is that the majority of investments in Region 4's SEZ have been manufacturing plants that require a large amount of labor. In contrast, those created in regions such as Metro Manila (NRC) tend to be software engineering and service oriented businesses with smaller staff requirements (Philippines Economic Zone Authority 2006b). ${ }^{3}$

\footnotetext{
${ }^{3}$ Note: Table 1 shows the number of jobs directly created within SEZ. It does not include peripheral jobs. In addition, there is a discrepancy between Fig. 1, the number of regions reporting SEZ, and
} 
Table 1 Job growth attributed to SEZ by selected Regions, 1995-2005

Bases Conversion Development Authority (2006b); Philippines Economic Zone Authority (2006b)

Table 2 Unemployment rates for Philippines, Regions 3 and 4, 1995-2005

National Statistical Coordination Board 2006

\begin{tabular}{lll}
\hline Region & Total SEZ Jobs & Percentage of SEZ Jobs \\
\hline CAR & 44,686 & 1.1 \\
NCR & $1,21,747$ & 2.9 \\
Region 3 & $1,456,718$ & 34.7 \\
Region 4 & $1,958,764$ & 46.6 \\
Region 7 & $5,73,578$ & 13.7 \\
Region 8 & 30,906 & 0.7 \\
Region 10 & 2,095 & 0.0 \\
Region 12 & 13,263 & 0.3 \\
\hline
\end{tabular}

\begin{tabular}{lccc}
\hline & Philippines (\%) & Region 3 (\%) & Region 4 (\%) \\
\hline 1995 & 7.5 & 8.7 & 9 \\
2000 & 8.4 & 10.1 & 11.3 \\
2005 & 10.3 & 12.5 & 14.1 \\
\hline
\end{tabular}

Since 1995, SEZ-created jobs in Regions 3 and 4 have grown faster and increased more in total jobs than in any of the Philippine's other regions. Since these figures do not include the peripheral/support jobs that economists and government officials anticipated would be generated with the establishment of SEZ, the total number of new jobs in these regions could be well over two million. Ironically, however, the creation of new jobs in SEZ has not resulted in lower unemployment levels in the affected regions. Not only has the unemployment rate increased in Regions 3 and 4 since the establishment of SEZ, but the rate of increase has been higher than elsewhere in the Philippines (See Table 2).

Paradoxically, at the same time that unemployment rates have increased in Regions 3 and 4, these regions experienced the highest population growth rates in the Philippines (2005 Philippines Statistical Yearbook, 2005). Moreover, our analysis of the components of population change showed that population growth in Regions 3 and 4 is largely the result of net in-migration. ${ }^{4}$ (See Table 3) Region 3 had a net migration of 8,51,757 between 2000 and 2005, 3,54,994 from 1995 to 2000 and 9,469 between 1990 and 1995. The same process showed that a net of 1,603,356 moved to Region 4 between 2000 and 2005, with an increase of 1,201,769 between 1995 and 2000 which is an increase of almost a million net inmigrants compared with 2,16,099 between 1990 and 1995. In contrast, Regions such

Footnote 3 continued

Table 1, the number of regions reporting jobs. For example, Fig. 1 indicates that Region 11 had nine SEZ but zero jobs. Any discrepancy between Fig. 1 and Table 1 can be attributed to one of two reasons. (1) The SEZ in a region did not report the number of jobs created to BCDA or PEZA, or (2) the SEZ was approved by BCDA or PEZA, but investors later pulled out. The later is the case of a number of SEZ in Region 7 where plans to open shipyards to repair supertankers were relocated to Singapore (Philippines Business Week, Nov. 11, 2004).

${ }^{4}$ We used the vital statistics method to estimate migration at the regional level between 1990 and 2005. 


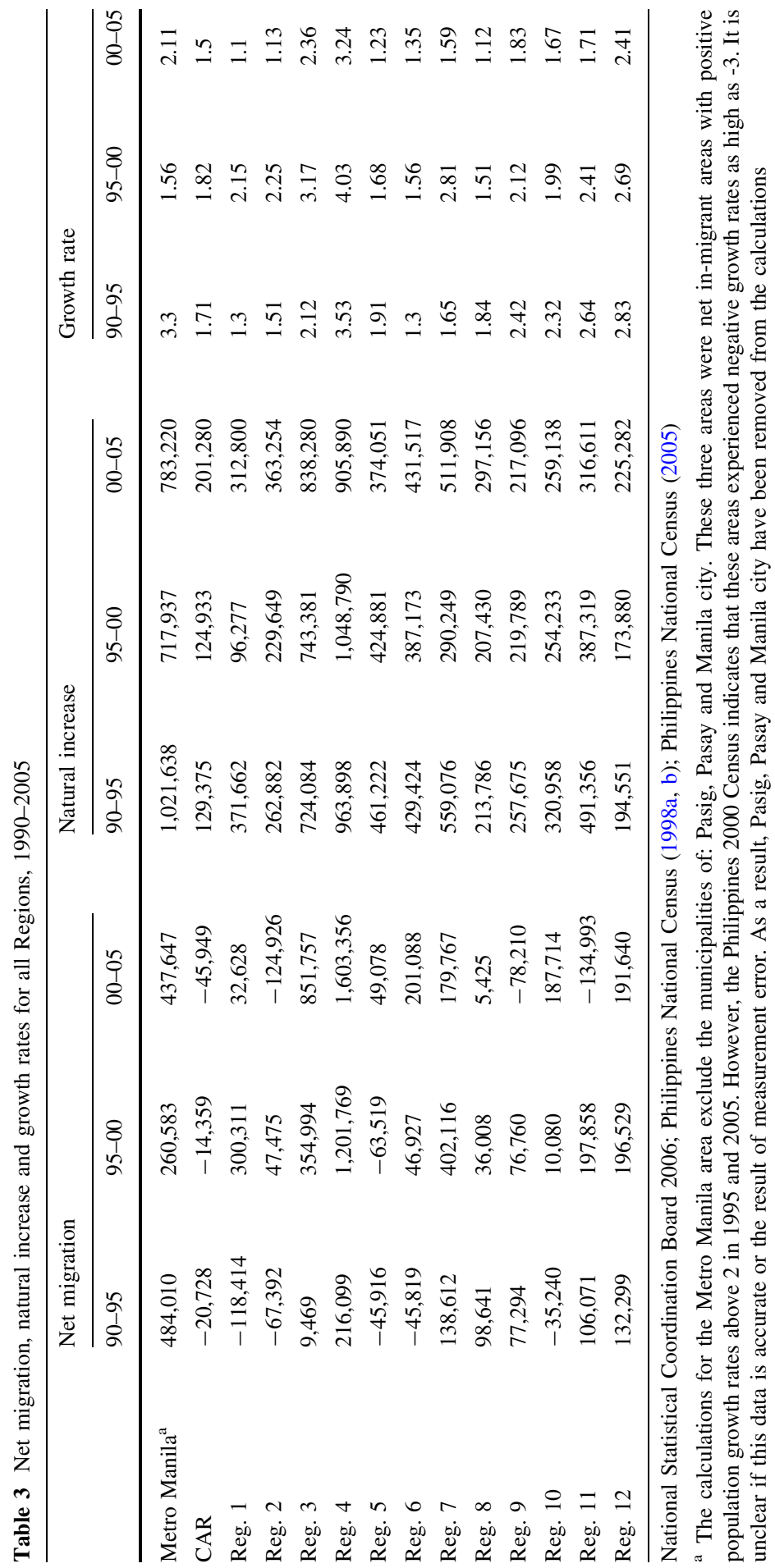


as 10 and 12 which created fewer SEZ jobs had much lower rates of population change and less net in-migration.

While these data show that Regions 3 and 4 were the destination for a substantial increase in net in-migration, they do not show the migrant origins or how patterns of migration flows have shifted since the establishment of the SEZ program in 1995. This information is needed to determine if the creation of SEZ by PEZA and BCDA resulted in new flows of in-migration and to identify regions of continuing outmigration where development policy might focus in the future. In addition, as is known from network-based theories of migration like cumulative causation, once a new migration stream is created, it will persist over time (Massey 1990; Massey 1999). This is because social networks are created that break down barriers to migration, increase the flow of information about economic and social conditions in the destination and reduce the overall risk of migrating to new areas. As a result, to understand the SEZ's effect on migration flows it is essential to know more than just net migration. We use the Harris and Todaro (1970) model to predict the origin, destination, magnitude and direction of migration flows in the Philippines between 1995 and 2005, since the inception of the PEZA and BCDA programs.

\section{Why Job Growth and Growth of Unemployment Rates Coincide in the Same Regions}

In cases where the job growth and the unemployment rate have both increased, the Harris-Todaro model can be used to predict the propensity of migration based on the expectation of wage gains. The model implies that if there is a sufficient difference between expected urban and rural wages it is economically rational for migration to occur from rural areas to urban areas even if both have high levels of unemployment. ${ }^{5}$ In other words, net rural to urban migration results in an increase in both urban population size and unemployment because the increased number of job seekers that migrate to an urban area and compete for available jobs will swell the unemployment rate's denominator.

The original Harris-Todaro model has been modified and simplified to fit varying market and labor conditions (Bell 1991; Fields 1975; Stiglitz 1974). The simplified Harris-Todaro model states that equilibrium is reached when the expected rural wage is equal to the expected urban wage when adjusted for the urban area's unemployment rates. The formal statement of the Harris-Todaro model is as follows:

- $\mathrm{w}_{\mathrm{r}}=$ the wage in the rural agricultural sector

- $1_{\mathrm{ue}}=$ the total number of employed urban workers

- $1_{\mathrm{us}}=$ the total number of job seekers in the urban sector

- $\mathrm{w}_{\mathrm{u}}=$ the wage in the urban sector

\footnotetext{
5 The Harris-Todaro model was developed to explain rural-urban migration in developing contexts. The terms "urban" and "rural," hence are generic labels for origin and destination. The model is not limited for use on rural-urban migration.
} 
At equilibrium,

$$
\mathrm{w}_{\mathrm{r}}=\frac{1_{\mathrm{ue}}}{1_{\mathrm{us}}} \mathrm{w}_{\mathrm{u}}
$$

In other words, equilibrium is reached when the expected rural wage $\left(\mathrm{w}_{\mathrm{r}}\right)$ equals the expected urban wage $\left(\mathrm{w}_{\mathrm{u}}\right)$, when the urban wage is multiplied by the number of available urban jobs $\left(l_{\mathrm{ue}}\right)$ over the total number of both unemployed and employed laborers in the urban sector $\left(\mathrm{l}_{\mathrm{us}}\right)$ or $\left(\frac{\mathrm{l}_{\mathrm{ue}}}{\mathrm{l}_{\mathrm{us}}}\right)$. If the urban wage $\left(\mathrm{w}_{\mathrm{u}}\right)$ after it has been adjusted for urban unemployment $\left(\frac{l_{u e}}{l_{u s}}\right)$ is higher than the rural wage $\left(\mathrm{W}_{\mathrm{r}}\right)$, then rural to urban migration is expected to occur:

$$
\mathrm{w}_{\mathrm{r}}<\frac{1_{\mathrm{ue}}}{1_{\mathrm{us}}} \mathrm{w}_{\mathrm{u}}
$$

Conversely, urban to rural migration will occur if:

$$
\mathrm{w}_{\mathrm{r}}>\frac{1_{\mathrm{ue}}}{1_{\mathrm{us}}} \mathrm{w}_{\mathrm{u}}
$$

Therefore, migration from rural areas to urban areas will increase if:

- Urban wages $\left(\mathrm{w}_{\mathrm{u}}\right)$ increase, increasing the expected urban income

- Urban unemployment $\left(\mathrm{l}_{\mathrm{us}}\right)$ decreases, increasing the expected urban income

- Urban job creation increases the number of available jobs in the urban sector $\left(l_{u e}\right)$, increasing the expected urban income

- Agricultural productivity decreases, lowering wages in the agricultural sector $\left(\mathrm{w}_{\mathrm{r}}\right)$, decreasing the expected rural income

Also, rural to urban migration is possible if the urban wage after it is discounted for the urban unemployment rate $\left(\frac{1_{\text {ue }}}{l_{\text {us }}} w_{u}\right)$ is lower than the rural wage rate $\left(\mathrm{w}_{\mathrm{r}}\right)$. Therefore, equilibrium is achieved when the discounted urban wage is equal to the rural wage.

The model is based on three assumptions: (1) that the labor pool has the skills needed to fill any job opening in either rural or urban labor markets, (2) agrarian employment, subsistence farming, day laborer etc., is always an option for people in rural areas and (3) migration is risk neutral. The first assumption is realistic with respect to SEZ. The overwhelming majority of the jobs created are low skill manufacturing and service jobs, and the skill set needed to obtain these jobs is common to most of the Filipino labor force. Therefore, it is unlikely that a significant number of urban jobs are being created that cannot be filled by rural migrants. The second assumption holds for many parts of the Philippines because employment rates in primarily rural regions rage from 96 to $99 \%$ (Philippines National Statistics Office 1998a). However, regions like Metro Manila and Regions 3 and 4, which are largely urban, have employment rates lower than $90 \%$. Therefore, to ensure that the model produces reliable migration estimates a modified Harris-Todaro model will be used where both rural and urban wage rates will be discounted by unemployment. 
In the modified Harris-Todaro model $l_{\text {re }}$ equals the total number of employed rural workers and $1_{\mathrm{rs}}$ equals the total number of job seekers in the rural sector. Rural unemployment, $1_{\mathrm{rs}}$ and $\mathrm{l}_{\mathrm{rs}}$, will then discount the rural wage, $\mathrm{w}_{\mathrm{r}}$, and be compared to the urban sector $\left(\frac{l_{\text {ue }}}{l_{\text {us }}} \mathrm{w}_{\mathrm{u}}\right)$. Therefore, at equilibrium the modified model is:

$$
\frac{1_{\mathrm{re}}}{1_{\mathrm{rs}}} \mathrm{w}_{\mathrm{r}}=\frac{1_{\mathrm{ue}}}{1_{\mathrm{us}}} \mathrm{w}_{\mathrm{u}}
$$

Finally, the third assumption assumes there is no risk or loss associated with migration. This assumption is not practical in the real world. There are many obvious risks associated in migration. Migrants could be promised a job, but none are available when they arrive in the new area, theft or accidents can occur during the actual migration, migrants could be socially rejected in their new communities or adequate housing may not be available in the new area. This assumption that migration is risk neutral causes the model to overstate the likelihood of migration. In order to adjust for this, we will only map significant migration flows, e.g., those with an HT-score that is $\leq 1.10$.

\section{Applying the Harris-Todaro Model to Inter-Regional Migration in the Philippines}

The Harris-Todaro model is a two-sector analysis between pairs of urban and rural regions. In order to apply the model and map the resulting migration flows throughout the Philippines, the model is calculated between pairs of regions, for example the Metro Manila area and Region 1. In every calculation the regional weighted average minimum wage is calculated from government data and used for either $\mathrm{w}_{\mathrm{r}}$ or $\mathrm{w}_{\mathrm{u}}$ depending on whether the region is considered to be urban or rural. The regional weighted average minimum wage is calculated by first determining the provincial average minimum wage by taking the provincial minimum wage for both rural and urban sectors and weighting them according to their respective populations. Once the provincial average minimum wage has been created for all the provinces in a region, the regional weighted average minimum wage is calculated by averaging the provincial weighted average minimum wages and weighting them by their respective total populations.

The selection of the urban labor sector or, $\frac{1_{\mathrm{ue}}}{\mathrm{I}_{\mathrm{us}}} \mathrm{w}_{\mathrm{u}}$ is based on the percentage of urban population for each region. For each calculation between two regions, the region with the higher percentage of urban population in each pair is designated as the urban sector and its regional weighted average wage is used to calculate $\mathrm{w}_{\mathrm{u} .}{ }^{6}$

\footnotetext{
${ }^{6}$ Urban and rural populations are based on 2005 PopCen definitions and held constant through each time period. The Philippine National Statistics Coordination Board defines barangay (similar to a village or neighborhood) as urban if a barangay: (1) has a population size of 5,000 or more, or (2) has at least one establishment with a minimum of 100 employees, or (3) has 5 or more establishments with a minimum of 10 employees, and 5 or more facilities within the $2 \mathrm{~km}$ radius from the barangay hall. Using this definition, the total urban and rural populations were aggregated to the regional level for 1995, 2000 and 2005 .
} 
Therefore the region with the lower percentage of urban population in each pair is selected as rural sector and its regional weighted average wage used as $\mathrm{w}_{\mathrm{r}}$. For example Metro Manila area, which has the highest percentage of urban population, is always selected as the urban region and its regional weighted average wage is used as $\mathrm{w}_{\mathrm{u}}$. For selection of the rural region, Cordillera Administrative Region (CAR) is always selected as the rural sector and $\mathrm{w}_{\mathrm{r}}$ because it has the lowest percentage of urban population. This process was used to determine the urban and rural sectors in each pair of the 91 possible pairings of regions in the Philippines. Each paired comparison was calculated for three time points: 1995, 2000 and 2005.

In order to map migration flows and determine the significance of their changes over time, the results of each Harris-Todaro model are expressed as the proportion $\frac{l_{\text {ue }}}{l_{u s}} \mathrm{~W}_{\mathrm{u}}$ over $\frac{1_{\mathrm{re}}}{l_{\mathrm{rs}}} \mathrm{w}_{\mathrm{r}}$ (see below). The resulting number is termed the HT score. To produce this score the equilibrium model was modified to:

$$
\frac{\frac{1_{\mathrm{ue}}}{l_{\mathrm{us}}} \mathrm{w}_{\mathrm{u}}}{\frac{1_{\mathrm{re}}}{l_{\mathrm{rs}}} \mathrm{W}_{\mathrm{r}}}=1, \quad \text { where } 1=\text { HT score }
$$

Rural to urban migration occurs when the HT score is greater than one, with the tendency for migration increasing with higher HT scores:

$$
\frac{\frac{1_{\text {ue }}}{l_{\text {us }}} \mathrm{W}_{\mathrm{u}}}{\frac{1_{\text {re }}}{1_{\mathrm{rs}}} \mathrm{W}_{\mathrm{r}}}>1
$$

Conversely, urban to rural migration will occur if the HT score is lower than one:

$$
\frac{\frac{l_{\mathrm{ue}}}{\frac{\mathrm{us}}{\mathrm{us}}_{\mathrm{u}}}}{\frac{\mathrm{l}_{\mathrm{re}}}{\mathrm{l}_{\mathrm{rs}}} \mathrm{W}_{\mathrm{r}}}<1
$$

\section{0-1995 Net Migration Flows According to the Harris-Todaro Model}

The resulting HT scores were used to map the migration predictions throughout the Philippines. By using ArcGIS and Tobler's Flow Mapper the variation and change of migration flows was mapped for the periods 1990-1995, 1995-2000 and 2000-2005.

The mapped flows (see Fig. 2) represent calculated differences between the expected wages in Regions 2, 8, 9, 10 and 12 and the expected wage in Metro Manila area between 1990 and 1995, and range from five to eight pesos per day. Figure three shows all migration flows with significant HT scores. All other regions reported either zero migration or insignificant HT scores. The data in Fig. 2 show migration flows to Manila predicted by the Harris-Todaro model between 1990 and 1995, when PEZA had just been established. As can be seen, only minor flows from smaller rural regions to Metro Manila area are predicted at that time. The map shows predicted migration flows with a HT score of $0.91-0.95$ which equals a 5-9\% difference in expected average daily regional wage. For example, the average regional wage after being discounted for unemployment in Region 8 is 88 pesos a 


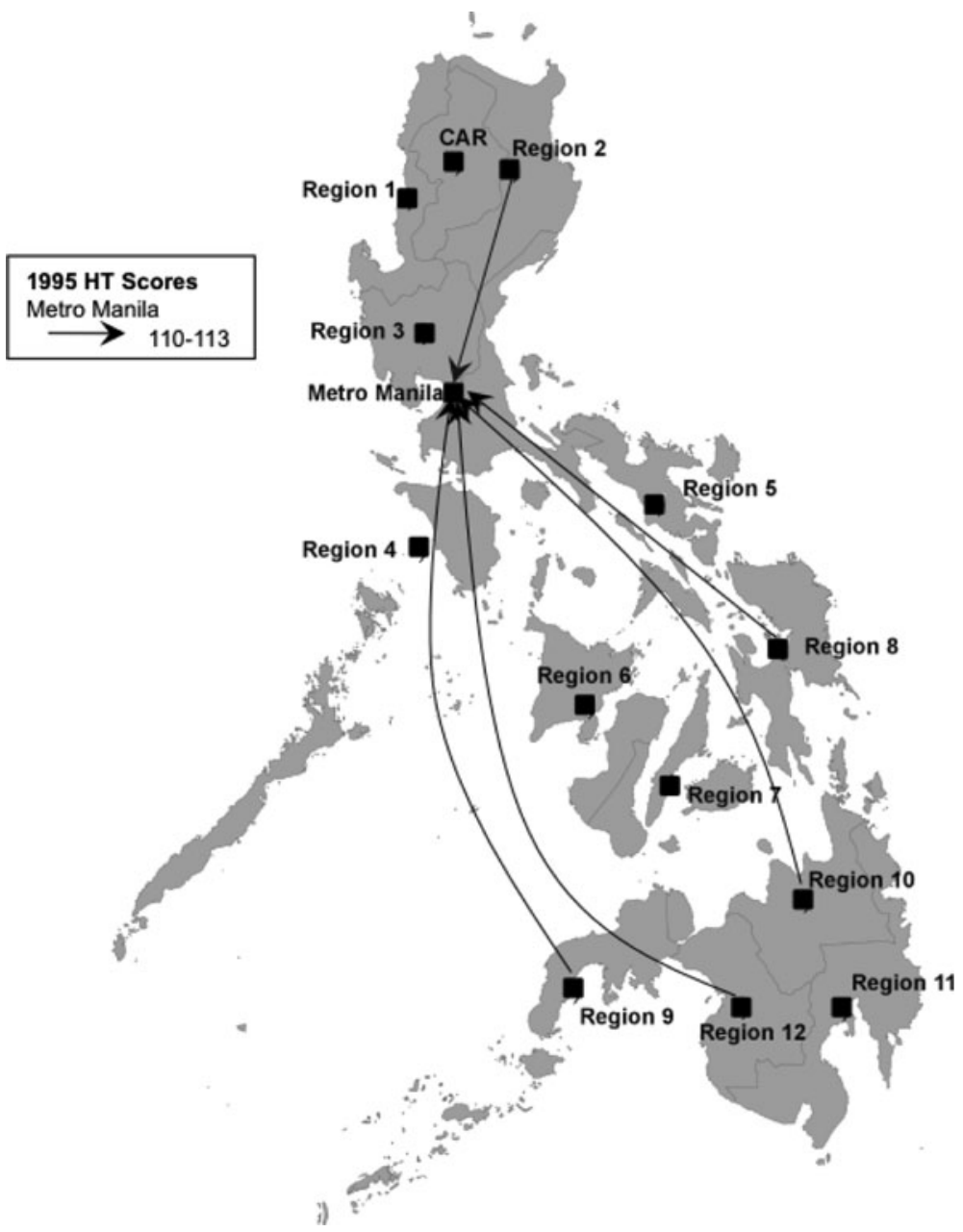

Fig. 2 Significant inter-regional HT migration flows Between 1990 and 1995

day while in Metro Manila Area the average wage after unemployment is accounted for is 101 pesos. That means the average worker in Region 8 can expect to earn 40 extra pesos a week if they choose to migrate to the Metro Manila Area.

These predictions are consistent with census migration data from 1990 to 1995 which show that most large migration flows within the Philippines originated in southern regions. In addition, the Harris-Todaro model indicates that Regions 8 and 9 had the highest propensity for migration. This finding is consistent with 1995 census data that indicated that Regions 8 and 9 had the highest number of migrants to the Metro Manila Area. The 1995 census indicated that Metro Manila gained 52,541 migrants from Region 9 and 46,452 migrants from Region 8 (Philippines National Statistical Coordination Board, 1997). These predictions are also consistent with 
population growth patterns for this time period. The Metro Manila Area reported higher annual growth rates than any other region between 1990 and 1995, 3.3\% compared with a national average of $2.3 \%$. Therefore, the migration tendencies predicted by the model are supported by census data and appear to accurately depict overall migration trends between 1990 and 1995.

\section{5-2000 Migration Flows Centered on the Metro Manila Area}

The Harris-Todaro model predicts an increase in the amount of interregional migration between 1995 and 2000 (see Fig. 3). The Metro Manila Area continued to be the largest destination for net in-migration with increased volumes of predicted

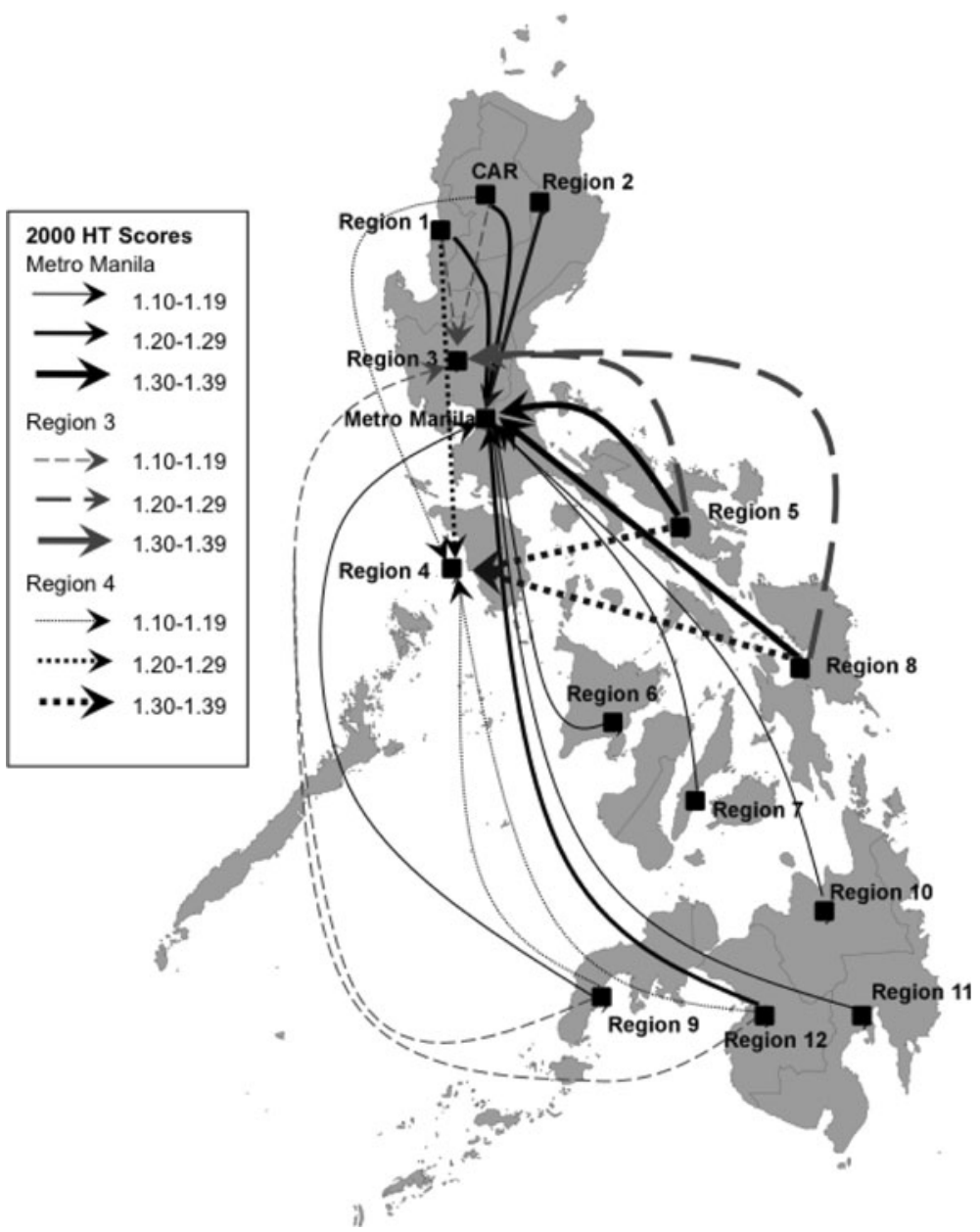

Fig. 3 Significant inter-regional HT migration flows Between 1995 and 2000 
in-migration from the existing 1990-1995 migration origin areas as well as from new regions. Region 5, located southeast of Manila, is predicted to have the highest propensity for out migration to Manila. Its HT Score of 1.32 equals a $43 \%$ difference in expected wages compared with the Metro Manila Area after unemployment in Metro Manila is accounted for. Even after unemployment is controlled, the expected average daily wage in Metro Manila compared with Region 5 is greater than 38 pesos a day, or a net gain of 192 pesos per week. Considering the average daily income for Region 5 was 89 pesos, this difference in income helps to illustrate why migration to the Metro Manila Area makes economic sense (Philippines National Statistical Coordination Board 2001).

\section{5-2000 Migration Flows Centered on Region 3}

The data in Fig. 3 show that Region 3 had the largest flows of in-migration from Regions 5, and 8 during 1995-2000 as well as other minor flows from CAR, Regions 1, 9 and 12. This is strikingly different than between 1990 and 1995 when Region 3 received very little migration from other regions. During this time Region 3 went from 9,469 net in-migrants between 1990 and 1995 to 354,994 net inmigrants between 1995 and 2000. It seems likely that increased migration to Region 3 is a result of job generation associated with SEZ established by both BCDA and PEZA. The largest flow to Region 3 originated from Region 8. The HT Score for migration from Region 8 to Region 3 is 1.32 or a $21.5 \%$ difference in the expected daily wage. This is equal to 19 pesos a day or 95 pesos a week.

This predicted migration flow between Regions 3 and 8 based on the HT model is supported by census data on ethnicity. Region 8 is the home of one of the Philippine's major ethnic groups, the Eastern Visayan and Waray. Between 1995 and 2000 Region 3 reported a $47 \%$ increase in the number of Visayans, and a $10 \%$ in the number of Waray (Philippines National Statistical Coordination Board 1998b; Philippines National Statistical Coordination Board 2006). Hence, the census ethnicity data provide corroborating support to the HT migration predictions for Region 3. ${ }^{7}$

\section{5-2000 Migration Flows Centered on Region 4}

Region 4 also experienced a dramatic increase in the amount of net in-migration between 1995 and 2000 (see Fig. 3). Migration flows to Region 4 are consistent with the region's increased population growth rate between 1995 and 2000. During

\footnotetext{
7 We acknowledge that there are limitations using ethnicity as means to support the models predicted findings. Due to the limitation of data, we do not know the specific origin of these new ethnic households. Many residents in Northern Mindanao, including Region 10, speak the Visayan language. We were not able to obtain more detailed migration and ethnicity census "public use data" from the NSO. However, while the data used to support the models findings are limited, results do show an increased south to north migration pattern consistent with the models findings and the theory of cumulative causation.
} 
this time, the annual population growth rate of Region 4 surpassed the growth rate of the Metro Manila Area and became the country's fastest growing region. It is likely that the rapid increase of jobs created within SEZ located in Region 4 contributed significantly to the increased number of migrants to Region 4.

The strongest predicted migration in-flows to Region 4 are from Regions 5 and 8. The difference in expected average daily wage when unemployment is account for in Region 4 is $19 \%$ or 17 pesos a day in Region 5, and $18 \%$ or 16 pesos a day in Region 8. Similar to Region 3, census data on ethnicity provide corroborating evidence consistent with the HT model's migration prediction for Region 4. In 2000, the National Statistics Office reported that Region 4 experienced a $45 \%$ increase in the number of people who classify themselves as Visayan and a $14 \%$ increase in Waray, the major ethnic groups in Region 8, and a 37\% increase in the number of people classifying themselves as Bikol, the major ethnic group in Region 5 (Philippines National Census 1998b; Philippines National Census 2006). The increase in Visayan and Bikol populations helps to account for the two largest migration in-flows to Region 4. The likelihood of migration to Region 4 from Region 5 and 8 is also supported by the fact that the national highway runs from Region 8 through Region 5 and directly into Region 4. Issah et al. (2005) report that the presence of infrastructure facilitates migration by removing potential logistical barriers for migrants and by increasing the flow of employment information between urban and rural areas (Issah et al. 2005). Accordingly, the 1995-2000 Harris-Todaro migration predictions for Region 4 are consistent with census data and other research findings.

\section{5-2000 Migration Flows and Estimates by the Residual Method}

Migration estimates using the residual method confirm the results derived from the Harris-Todaro method. While residual estimates yield a net migration figure for each region, they do not produce flows data between various origin and destination regions as is possible with the Harris-Todaro method. Accordingly, the residual migration analysis is presented as a way of evaluating the reliability of the HarrisTodaro estimates shown above. The residual population was calculated for all regions between 1995 and 2000. This was done for each region by subtracting the total number of registered deaths from the total number of registered births. The resulting natural increase was then subtracted from the difference in population between 1995 and 2000. Compared with 1995, Region 4 had a residual population of 1,201,769 in 2000 while Region 3 had a residual population of 3,54,944. These two regions had the highest net in-migration in the Philippines between 1995 and 2000. In contrast, Region 5 had a substantial net migration loss with a residual of 63,519. Regions 8, 9 and CAR also recorded negative residual populations or a decrease in net in-migration, which are consistent with the 2000 HT-scores. While these data do not show origins and destinations of the migration flows, they confirm that net in-migration is occurring to Regions 3 and 4 at the same time that net outmigration is occurring in Regions 5, 8, 9 and CAR. 


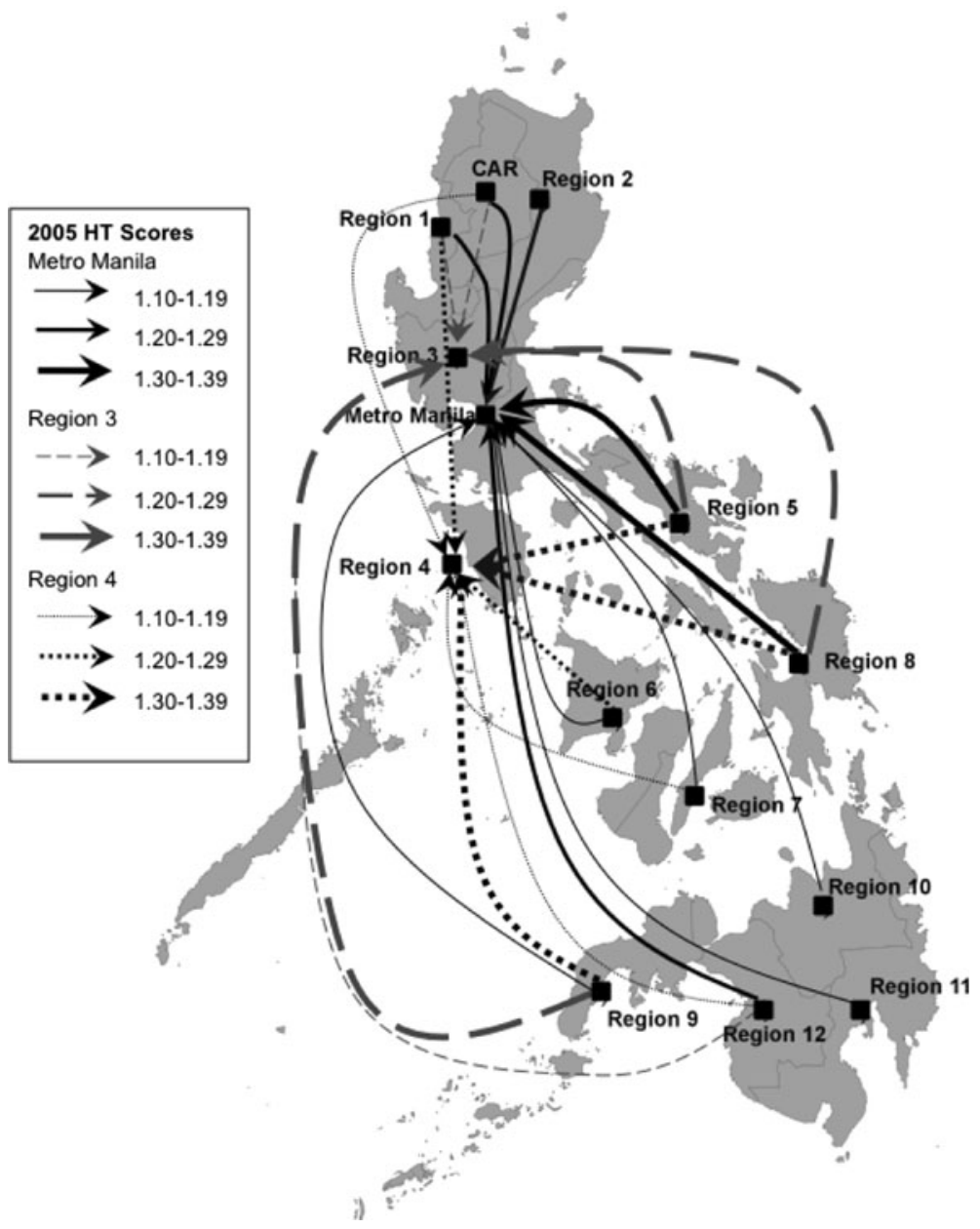

Fig. 4 Significant inter-regional HT migration flows Between 2000 and 2005

\section{Migration Flows Between 2000 and 2005}

The data in Fig. 4 show that the migration flows to the Metro Manila Area predicted by the HT model for 2000-2005 are similar to those predicted during the previous 5 years. Although there are some slight variations in the magnitude of the flows, the overall trends are similar to those predicted between 1995 and 2000. The 2005 model predicts that Metro Manila has remained the Philippines major destination for internal migration.

The data in Fig. 4 also show migration flows to Regions 3 and 4 during 2000 and 2005. These data indicate that Region 3 continued to attract migrants from southern regions between 2000 and 2005 . However, the largest source of in-migration shifted from Regions 5 and 8 in 2000 to Region 9 during the 2000-2005 period. All other 
2005 migration predictions for Region 3 were similar to those shown for 2000 . The 2000-2005 HT model predictions for Region 4 show that migration flows to the region originated in an increased number of locations. Overall, the model shows that migration to Region 4 continued to increase in 2005 and are consistent with residual estimations of migration that show negative net migration in Region 9 with decreased net migration in Regions 1,8 and 12 .

Mapping predicted migration flows with the modified Harris-Todaro model illustrated that migration flows have shifted to Regions 3 and 4 after PEZA and BCDA began locating SEZ in these regions. This indicates that the jobs created in the SEZ in Regions 3 and 4 have increased the number of migrants to the area, which helps to explain why both population and the rate of unemployment have steadily increased in Regions 3 and 4 since 1995.

In addition, it is likely that increased migration to Regions 3 and 4 will continue. Consistent with Massey's theory of cumulative causation, each additional migrant helps to create the social structure needed to sustain further migration flows (Massey 1990; Massey 1999). Social networks and capital flows between origins and destinations increase the flow of information about the job market, housing and other living conditions, thereby reducing the costs and risks associated with migration. As a result, once a new migration flow is created it will increase in strength over time. The analysis shows that Regions 3 and 4 became new destinations for internal migrants during 1995 and 2000, subsequent to the establishment of the PEZA and BCDA development programs and their resulting SEZ. Moreover, these new migration flows to Regions 3 and 4 between 1995 and 2000 increased in strength during the next 5 years, indicating that the social structures promoting migration to these areas has strengthened. Hence, the HarrisTodaro predictions of Filipino migration flows between 1995 and 2005 are consistent with migration theory and reflect PEZAs and BCDAs roles in redistributing the nation's population.

\section{Conclusions and Policy Implications}

The implementation of PEZA and BCDA in 1995 has resulted in substantial population redistribution within the Philippines. Consistent with the Harris-Todaro model, rural workers moved from low wage rural areas to more highly urbanized regions where the PEZA and BCDA programs had established SEZ as the location of highly subsidized economic development schemes. This research shows that this population redistribution increases the pressure on urban labor markets to integrate a growing number of potential workers. Accordingly, the urban unemployment rate has tended to increase because the number of in-migrating workers has exceeded the number of new jobs created. Our analysis shows that high levels of rural to urban migration result between 1995 and 2005 in regions where the PEZA and BCDA programs have produced the most jobs. Moreover, the research showed that these same regions experienced increased higher than average increases in unemployment despite the large number of jobs created by PEZA and BCDA. If reduced unemployment is one of PEZA's and BCDA's goals, we believe that program 
managers should take the geo-spatial location of SEZ into consideration, and direct FDI into areas with a lower propensity for in-migration. Because migration data from the Philippines national census is limited, this research suggests that PEZA and BCDA consider using the modified Harris-Todaro model to identify geographical areas with a low current migration potential. As a result, they would be able to map internal migration between origins and destinations thereby identifying locations where economic development would absorb excess rural labor rather than stimulating rural out-migration to Manila or Regions 3 and 4 where SEZ are currently concentrated. In addition, since the model is based on quarterly provincial minimum wages, inter-provincial migration estimates could be updated frequently thereby providing an accurate representation of current migration trends and potentials.

\section{Using the HT Scores to Identify Potential SEZ Sites}

Figure 5 demonstrates how PEZA and BCDA officials could use the modified Harris-Todaro model to identify future SEZ locations. By using an advanced interpolation technique in ArcGIS called kriging, a map can be produced that shows the variation of migration likelihoods throughout the Philippines (ESRI 2007). Kriging uses the average HT score for each region, and then calculates the value of unknown cells across a statistical surface. The resulting map then shows the average HT score for 2005 across the entire Philippines. From this map it is easy to recognize areas that have an average $\mathrm{HT}$ score below 1 indicating a low propensity for in-migration. PEZA, BCDA and potential investors can then overlay the location of national highways, major ports, airports and other variables that investors require to find a location that meets both the business and logistical needs of future investors and is located in an area currently experiencing low in-migration (Philippines Economic Zone Authority 2006b).

Figure 5 was calculated using the 2005 HT scores. Areas with the highest propensity for in-migration are shown in black; areas with the lowest potential are colored white. As expected, the map shows that the Metro-Manila area and parts of Region 3 and 4 have the highest tendency for in-migration. According to the HarrisTodaro model, any additional development or job creation in these areas is likely to increase the migration flow, causing additional pressure on urban labor markets and a probable increase in unemployment rates. In contrast, the analysis identifies four areas with low migration potential that might be good locations for future SEZ sites.

Starting in the north, the analysis identifies the Laoag metropolitan area as a potential location for future SEZ. The city is connected with the Metro Manila area by national highways and has convenient access to a number of ports in the region. It also has the third largest international airport in the Philippines with regularly scheduled flights to Taiwan. San Fernando metropolitan area is another possible sight for SEZ in the northern Philippines. The city has the largest port in the northern Philippines and is connected to Manila by multiple highways. Locating SEZ in either of these locations would help to establish an economic center for the northern Philippines. In addition, because of the region's current low propensity of 
in-migration, new jobs created in either of these locations are not likely to result in increased unemployment rates and regional out-migration.

The Iloilo metropolitan area and Metropolitan Cebu are also possible locations for future SEZ given that have the second and third largest ports in the Philippines respectfully. Cebu also has the second largest airport in the Philippines. The one drawback of locating in this area is a lack of national highway connections with the rest of the nation's spatial economy. Because these two cities are located on islands, ground transportation is limited. However, because companies in SEZ must be engaged in exportation, the large ports and airports located there would seem to be

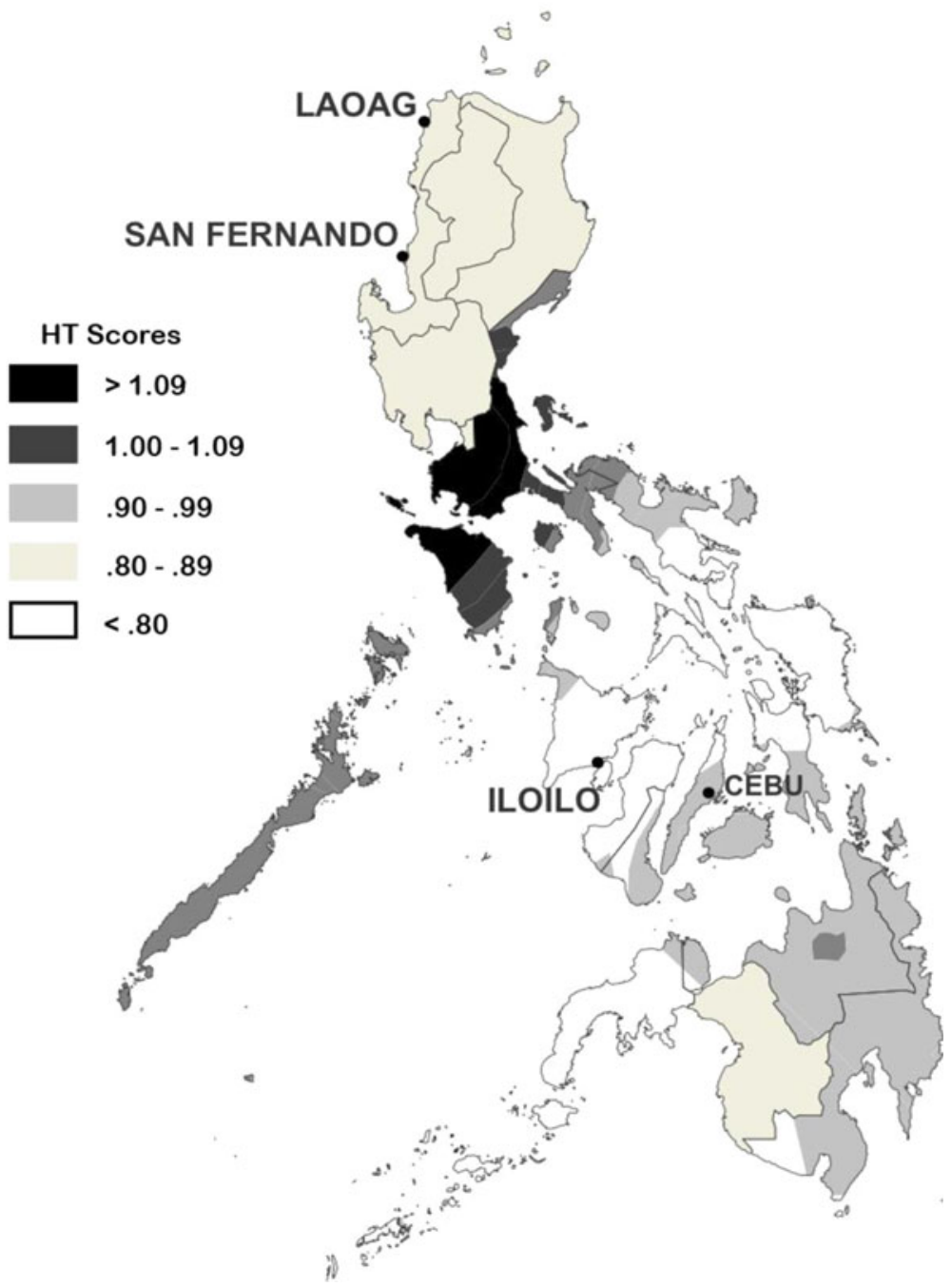

Fig. 5 Map of 2005 HT scores showing migration tendencies 
strong inducement for many investors. Also, based on the Harris-Todaro model, these areas have some of the highest current out-migration flows in the country. The formation of an economic center in the southern tier of the Philippines similar to the one established by PEZA in Region 4 would help to alleviate migration to MetroManila as well as to Regions 3 and 4. As a result, economic development would be spread more widely throughout the nation, and the pressure on urban labor markets might be lessened thereby diminishing the urban unemployment rate.

This paper demonstrates the benefits of considering policy impacts at a disaggregated regional level. The regional level migration model used in this research illuminates how the Philippines' regional development policies (PEZA and BCDA) have affected regions differently by placing SEZ in some regions rather than in others. As a consequence, PEZA and BCDA contribute to regional inequality, stimulating job and population growth in some areas and out-migration from others. The Harris-Todaro model and GIS techniques used in this research demonstrate how spatial models can be used by policymakers for gaining insights into the relative merits of alternative locations as sites of future SEZ.

\section{Appendix}

See Appendix Table 4, 5 and 6. 


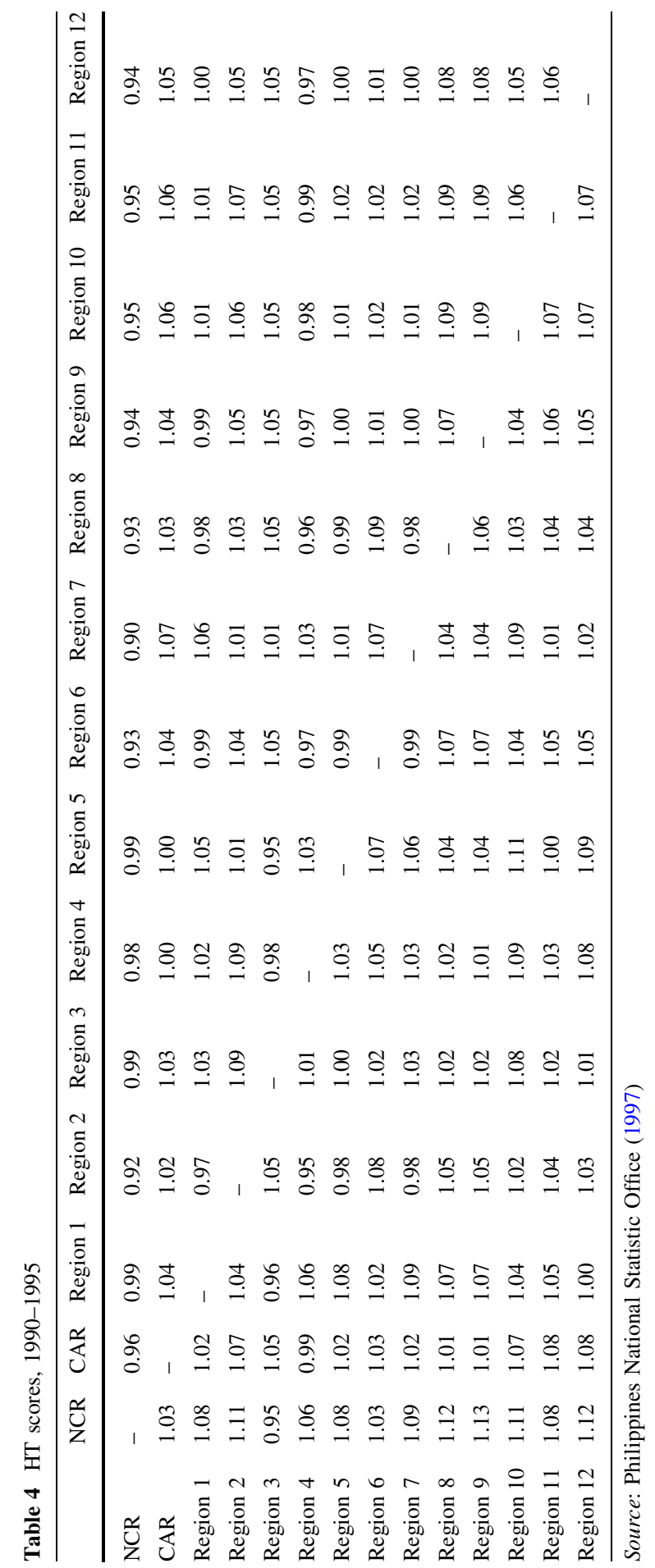




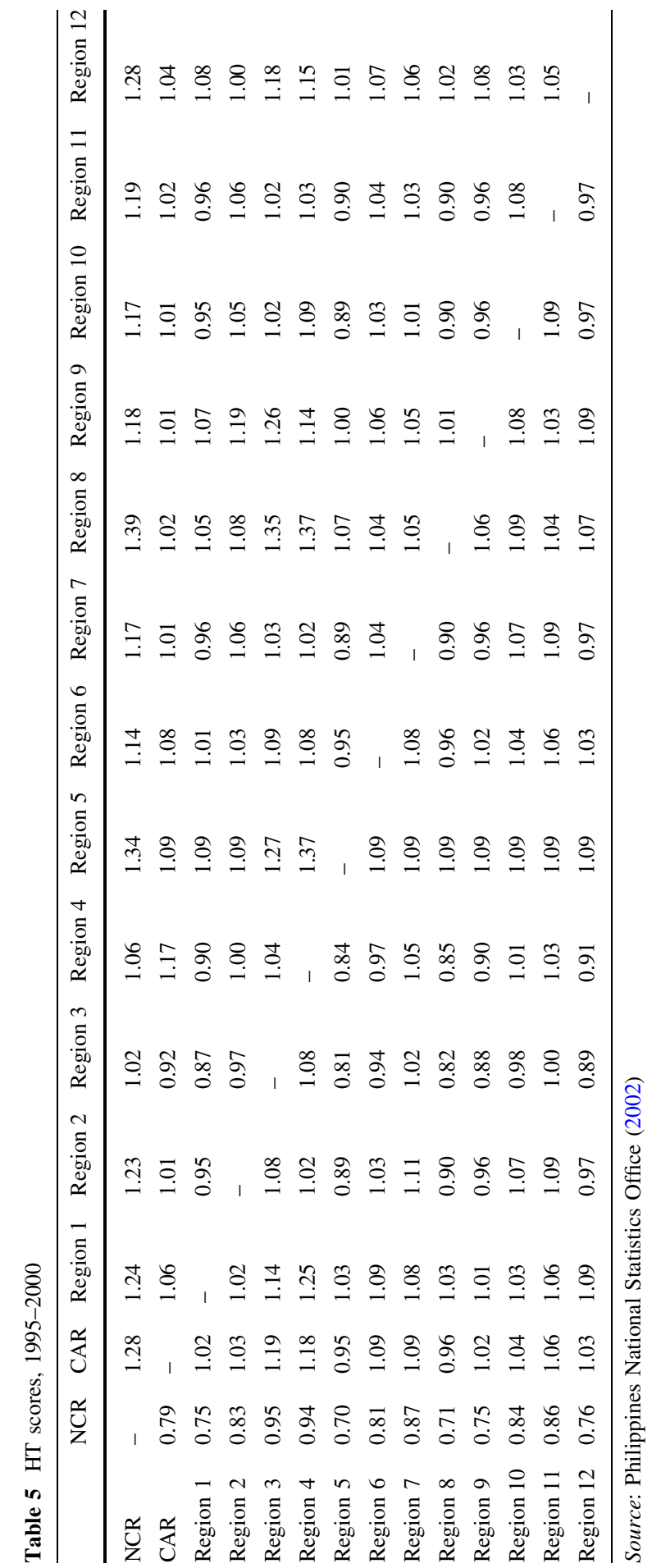




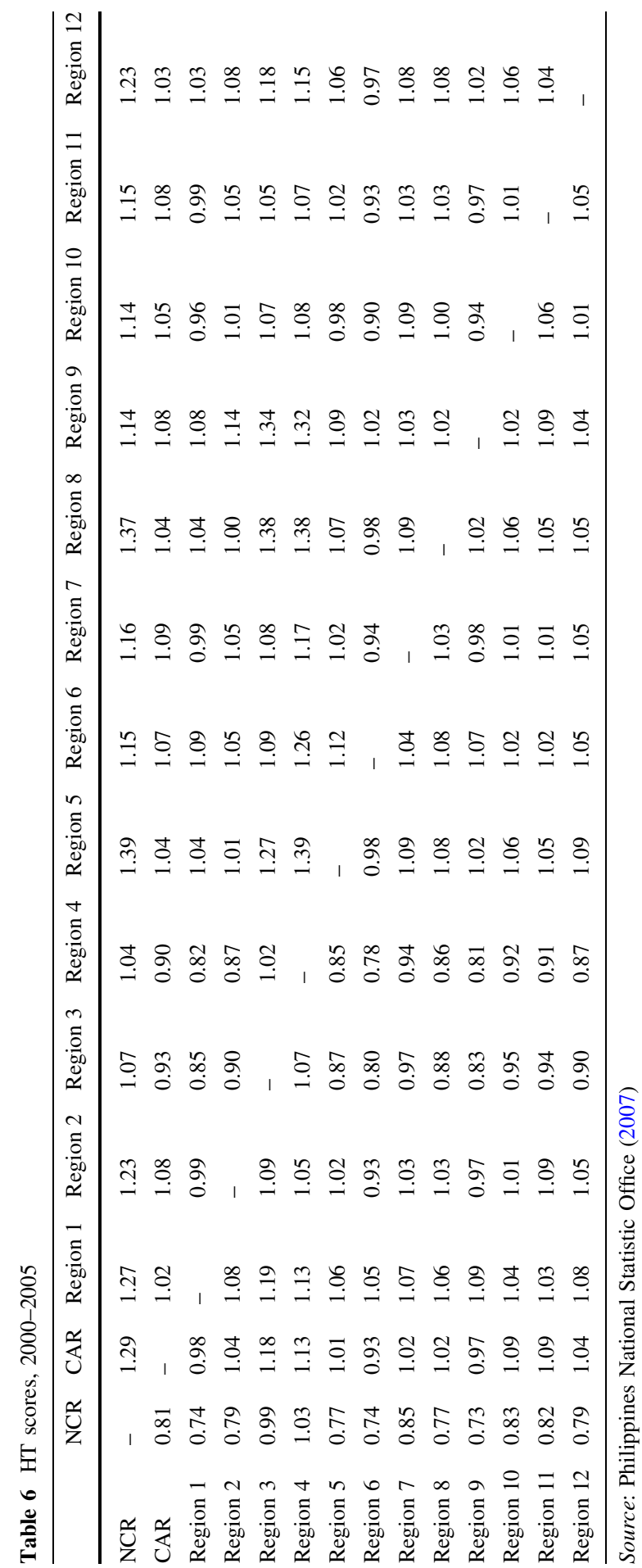




\section{References}

Bases Conversion Development Authority. (2001). Annual report 2000.

Bases Conversion Development Authority. (2006a). About the BCDA. Retrieved March, 19, 2006, from http://www.bcda.gov.ph.

Bases Conversion Development Authority. (2006b). Annual report 2005.

Bell, C. (1991). Regional heterogeneity, migration, and shadow prices. Journal of Public Economics, 46(1), 1-27.

ESRI. (2007). Understanding different kriging models. Retrieved September 6, 2007, from http://web help.esri.com/arcgisdesktop/9.2/index.cfm?TopicName=Understanding_different_kriging_models.

Fields, G. S. (1975). Rural-urban migration, urban unemployment and underemployment, and job-search activity in LDCs. Journal of Development Economics, 2(2), 165-187.

Guillermo, V. (1996). Checking out employment strategies. Manila: Press Foundation of Asia.

Harris, J. R., \& Todaro, M. P. (1970). Migration, unemployment and development: A two-sector analysis. The American Economic Review, 60(1), 126-142.

Issah, I., Khan, T. Y., \& Sasaki, K. (2005). Do migrants react to infrastructure difference between urban and rural areas? Development of an extended Harris-Todaro model. Review of Urban and Regional Development Studies, 17(1), 68-88.

Makabenta, M. P. (2002). FDI location and special economic zones in the Philippines. Review of Urban and Regional Development Studies, 14(1), 59.

Massey, D. S. (1990). Social structure, household strategies, and the cumulative causation of migration. Population Index, 56(1), 3-26.

Massey, D. S. (1999). Why does immigration occur? In C. Hirschman, P. Kasinitz, \& J. DeWind (Eds.), The handbook of international migration: The American experience (pp. 34-52). New York: New Russell Sage Foundation.

National Statistical Coordination Board. (2001). 2000 Philippines statistical yearbook. Manila: National Statistical Coordination Board.

Philippines Congressional Planning and Budget Department. (2003). Economic and employment status report.

Philippines Economic Zone Authority. (2006a). About PEZA. Retrieved April, 23, 2006, from http://www.peza.ph.gov.

Philippines Economic Zone Authority. (2006b). Philippines special economic zones. Retrieved April 23, 2006, from http://www.peza.gov.ph.

Philippines Economic Zone Authority.(2006c). SEZ employment totals. Unpublished report.

Philippines National Census. (1997). Provincial profile: National capital region. Manila: National Statistical Board.

Philippines National Census. (1998a). PopCens 95. Manila: National Statistical Board.

Philippines National Census. (1998b). Socio-economic and demographic characteristics, 1995. Manila: National Statistical Board.

Philippines National Statistics Office. (2002). Philippines statistical yearbook, 2001. Manila: Bureau of the Census and Statistics.

Philippines National Census. (2005). Socio-economic and demographic characteristics, 2000. Manila: Bureau of the Census and Statistics.

Philippines National Census. (2006). Socio-economic and demographic characteristics, 2000. Manila: National Statistical Board.

Ringuet, D. J., \& Estrada, E. (2003). Understanding the Philippines' economy and politics since the return of democracy in 1986. Contemporary Southeast Asia, 25(2), 233.

Stiglitz, J. E. (1974). Alternative theories of wage determination and unemployment in LDC's: The labor turnover model. The Quarterly Journal of Economics, 88(2), 194-227.

Tolentino, M. P. (1994). Developing agriculture toward sustainable industrialization. Economics and business in the Philippines (pp. 57-68). San Francisco: The Asia Foundation. 